Original Article

\title{
Isolation and characterization of bacteria associated with silkworm gut under antibiotic-treated larval feeding
}

\author{
Isolamento e caracterização de bactérias associadas ao trato intestinal do \\ bicho-da-seda sob alimentação larval tratada com antibióticos
}

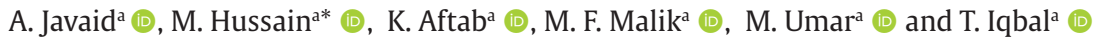 \\ aUniversity of Gujrat, Department of Zoology, Punjab, Pakistan
}

\begin{abstract}
The impact of antibiotics on growth, cocoon production was assessed in addition to isolation and characterization of bacteria associated with silkworm gut of infected larvae. Larval rearing was maintained at recommended conditions of temperature and humidity. Silkworm larvae showing abnormal symptoms were collected from the control group and dissected for gut collection. Bacteria were isolated from the gut content by spreading on agar plates and incubated at $37{ }^{\circ} \mathrm{C}$ for $48 \mathrm{hrs}$. Bacterial identification and phylogenetic analysis were carried out by $16 \mathrm{~S}$ rRNA gene sequencing. The isolated bacteria were subjected to antimicrobial susceptibility test (disc diffusion methods) by using Penicillin (10 $\mu \mathrm{g} / \mathrm{mL})$, Tetracycline $(30 \mu \mathrm{g} / \mathrm{mL})$, Amoxicillin $(25 \mu \mathrm{g} / \mathrm{mL})$, Ampicillin $(10 \mu \mathrm{g} / \mathrm{mL})$, and Erythromycin $(15 \mu \mathrm{g} / \mathrm{mL})$. All isolated strains showed positive results for the catalase test. We isolated and identified bacterial strains $(\mathrm{n}=06)$ from the gut of healthy and diseased silkworm larvae. Based on the 16S rRNA gene sequence, isolated bacteria showed close relation with Serratia, Bacillus, and Pseudomonas spp. Notably, 83.3\% of strains were resistant to Penicillin, Tetracycline, Amoxicillin, Ampicillin, and Erythromycin but 16.6\% showed antibiotic susceptibility to the above-mentioned commonly used antibiotics. Silkworm larvae fed on penicillintreated leaves showed significant improvement in larval weight, larval length, and cocoon production. Significantly higher larval weight $(6.88 \mathrm{~g})$, larval length $(5.84 \mathrm{~cm})$, and cocoon weight $(1.33 \mathrm{~g})$ were recorded for larvae fed on leaves treated with penicillin as compared to other antibiotics. Isolated bacterial strains showed close relation with Serratia spp., Bacillus spp. and Pseudomonas spp.
\end{abstract}

Keywords: chinese race, silkworm gut, bacterial pathogens, B. mori, sericulture.

\begin{abstract}
Resumo
O impacto dos antibióticos no crescimento e na produção do casulo foi avaliado, além do isolamento e caracterização das bactérias associadas ao intestino de larvas infectadas do bicho-da-seda. A criação das larvas foi mantida nas condições recomendadas de temperatura e umidade. As larvas do bicho-da-seda com sintomas anormais foram coletadas do grupo controle e dissecadas para coleta do intestino. As bactérias foram isoladas do conteúdo intestinal por espalhamento em placas de ágar e incubadas a $37^{\circ} \mathrm{C}$ durante 48 horas. A identificação bacteriana e a análise filogenética foram realizadas pelo sequenciamento do gene $16 \mathrm{~S}$ rRNA. As bactérias isoladas foram submetidas a teste de sensibilidade antimicrobiana (métodos de difusão em disco) com penicilina (10 $\mu \mathrm{g} / \mathrm{mL}$ ), tetraciclina $(30 \mu \mathrm{g} / \mathrm{mL})$, amoxicilina $(25 \mu \mathrm{g} / \mathrm{mL})$, ampicilina $(10 \mu \mathrm{g} / \mathrm{mL})$ e eritromicina $(15 \mu \mathrm{g} / \mathrm{mL})$. Todas as cepas isoladas apresentaram resultados positivos para o teste da catalase. Isolamos e identificamos cepas bacterianas $(\mathrm{n}=06$ ) do intestino de larvas de bicho-da-seda saudáveis e doentes. Com base na sequência do gene 16S rRNA, as bactérias isoladas mostraram estreita relação com Serratia, Bacillus e Pseudomonas spp. Notavelmente, $83,3 \%$ das cepas eram resistentes a penicilina, tetraciclina, amoxicilina, ampicilina e eritromicina, mas 16,6\% mostraram suscetibilidade aos antibióticos comumente usados mencionados acima. As larvas do bicho-da-seda alimentadas com folhas tratadas com penicilina apresentaram melhora significativa no peso larval, comprimento larval e produção de casulo. Peso larval significativamente maior $(6,88 \mathrm{~g})$, comprimento larval $(5,84 \mathrm{~cm})$ e peso do casulo $(1,33 \mathrm{~g})$ foram registrados para larvas alimentadas com folhas tratadas com penicilina, em comparação com outros antibióticos. Cepas bacterianas isoladas mostraram estreita relação com Serratia spp., Bacillus spp. e Pseudomonas spp.
\end{abstract}

Palavras-chave: raça chinesa, intestino de bicho-da-seda, patógenos bacterianos, B. mori, sericultura.

*e-mail: dr.mubashar@uog.edu.pk

Received: March 10, 2021 - Accepted: July 18, 2021

This is an Open Access article distributed under the terms of the Creative Commons Attribution License, which permits unrestricted use, distribution, and reproduction in any medium, provided the original work is properly cited. 


\section{Introduction}

Sericulture is rearing domesticated silkworms and the cultivation of mulberry for raw silk production. Sericulture industry has great potential to increase the quantity and improve the quality of silk fiber (Hussain et al., 2011a). Silkworm domestication resulting in inbreeding depression, and variations in climatic conditions and diseases pose great menace to the sericulture industry (Kanwal et al., 2018). This requires improving the rearing conditions, improved silk seed, vigorous management practices, disease management, and availability of separate rearing rooms (Islam et al., 2004; Hussain et al., 2011b; Sharma \& Kedar, 2013; Todmal et al., 2013). The pathogenic microbial infections of Bombyx mori induce a shift in the metabolic profiles and affect the activities of enzymes amylase, invertase, trehalase, and protease (Sidhu \& Singh, 1968) resulting in the spoilage of cocoon and silk quality (Venkatesh \& Kumaran, 2015).

Pseudomonas spp., Staphylococcus spp., Streptococcus bombycis, Serratia marcescens, Micrococcus spp., Bacillus spp. and Bacillus thuringiensis have been reported associated with significant cocoon crop losses by weakening the immunity of silkworm (Choudhury et al., 2002; Rajendra et al., 2011). Haemolymph plays a key role in the innate immune response triggered by bacterial action (Hou et al., 2010). Antibiotics exhibit therapeutic and healing effects in B. mori larvae septic with bacterial pathogens (Mohanta et al., 2013). Antibiotics used for the treatment of mammals exhibited therapeutic and healing effects in B. mori larvae septic with bacterial pathogens (Nayak et al., 2006). Antibiotics have been used in silkworm rearing for the management of diseases, promotion of growth, and improve feed consumption (Mohanta et al., 2013).

The impact of various antibiotics on silkworm growth, disease management, and study of gut bacteria during larval rearing has been explored in various parts of the world in the recent past (Liang et al., 2015; Liang et al., 2014; Sun et al., 2016). Bacteria play a crucial role in the digestion of mulberry leaf constituents by producing digestive enzymes in the midguts (Dillon \& Dillon, 2004). Thus, the study of bacterial communities associated with silkworm gut needs to be conducted concerning different feeding environments, silkworm strains, and mulberry varieties. The current study was conducted to evaluate the impact of antibiotic-treated larval feeding on growth, cocoon production, and bacteria associated with the silkworm gut.

\section{Materials and Methods}

The impact of antibiotics on growth, cocoon production was assessed in addition to isolation and characterization of bacteria associated with silkworm gut of infected larvae. The rearing was carried out in the Laboratory of Systematics and Pest Management, Department of Zoology, University of Gujrat, Punjab, Pakistan.

\subsection{Incubation of silkworm eggs}

The eggs of the Chinese race of silkworm were obtained from Sericulture Research Laboratory Lahore and incubated at $24 \pm 2{ }^{\circ} \mathrm{C}$ and $75 \pm 5 \%$ Relative Humidity ( $\mathrm{RH}$ ) with a photoperiod of 16 hrs light: 08 hrs darkness.

\subsection{Rearing procedure}

The rearing was carried out in rearing trays and early larval instars $\left(1^{\text {st }} 3^{\text {rd }}\right)$ were fed mulberry leaves of local variety at an interval of 6 hrs. Late instar larvae $\left(4^{\text {th }}-5^{\text {th }}\right.$ instars) were divided into six groups and each replicated thrice. Early instar larvae were raised at $28{ }^{\circ} \mathrm{C}$ and $80 \pm 5 \%$ RH whereas late instar larvae $\left(4^{\text {th }}-5^{\text {th }}\right.$ instars $)$ were reared at $26 \pm 2{ }^{\circ} \mathrm{C}$ and $70 \pm 5 \% \mathrm{RH}$.

\subsection{Antibiotic treatment}

Tetracycline $(30 \mu \mathrm{g} / \mathrm{mL})$, Amoxicillin $(25 \mu \mathrm{g} / \mathrm{mL})$, Ampicillin $(10 \mu \mathrm{g} / \mathrm{mL})$, Erythromycin $(15 \mu \mathrm{g} / \mathrm{mL})$ and Penicillin $(10 \mu \mathrm{g} / \mathrm{mL})$ were used in the study. The mulberry leaves dipped in the antibiotic solutions were fed during the $4^{\text {th }}$ and $5^{\text {th }}$ instar larvae (Mahmoud et al., 2012). The silkworm larvae were fed on antibiotic-treated mulberry leaves during the $4^{\text {th }}$ and $5^{\text {th }}$ instars at an interval of 12 hrs.

\subsection{Bacterial strains isolation antimicrobial susceptibility test}

In the $4^{\text {th }}$ and $5^{\text {th }}$ instar, silkworm larvae with symptoms of infection (loss of appetite, sluggish larvae, evacuation of loose bowel and motionless, discolored, and flaccid) were collected from control groups and dissected for gut collection. All such larvae were immediately removed from other stock and maintained separately. It was processed for gut content collection and bacterial isolation followed by grinding in $10 \mathrm{~mL}$ sterile saline water, spreading on agar plates, and incubation at $37^{\circ} \mathrm{C}$ for $48 \mathrm{hrs}$ for culture growth.

\subsection{Collection of diseased larvae and isolation of bacteria}

Bacteria were isolated from randomly selected diseased larvae $(n=06)$. The bacterial strains were isolated from the gut of larvae. The larvae were disinfected in $2 \%$ Sodium hypochlorite for 3 to $5 \mathrm{~min}$ and afterward, gut material was collected from dissected larvae and suspended in sterile saline water and spread on agar medium incubating at $37{ }^{\circ} \mathrm{C}$ overnight for bacterial culture. The bacterial cultures were purified through the streak plate method and bacterial strains isolated from healthy larvae (HG) from the treated groups were designated as HG1, HG2, and HG3 whereas those collected from diseased larvae (DG) were designated as DG1, DG2, and DG3. The purified colonies of each sample were further cultured in the nutrient broth at $37^{\circ} \mathrm{C}$ overnight in a shaking incubator for different biochemical tests i.e. catalase, mannitol, and citrate test. The isolated bacterial strains were permanently stored in $15 \%$ glycerol.

\subsection{Biochemical characterization and antimicrobial susceptibility test}

The isolated bacterial strains were subjected to multiple metabolic and biochemical tests including catalase, citrate utilization, and mannitol utilization test. The antimicrobial susceptibility was carried out using the Kirby-Bauer disc diffusion method (Ayoade et al., 2014; Bauer et al., 1966) for commonly used antibiotics including Penicillin (10 $\mu \mathrm{g} / \mathrm{mL})$, Tetracycline $(30 \mu \mathrm{g} / \mathrm{mL})$, Amoxicillin $(25 \mu \mathrm{g} /$ $\mathrm{mL})$, Ampicillin $(10 \mu \mathrm{g} / \mathrm{mL})$ and Erythromycin $(15 \mu \mathrm{g} / \mathrm{mL})$. 
The diameters of inhibition zones were measured after overnight incubation at $37^{\circ} \mathrm{C}$ (Riaz et al., 2011).

\subsection{Isolation of DNA}

Colony PCR was used for the amplification of 16S rRNA gene amplification. Briefly, a separate bacterial colony was picked and added to the $\mathrm{PCR}$ reaction mixture and incubated for extra 5 minutes at $95^{\circ} \mathrm{C}$ in the initial denaturation step to lyse bacterial cells and obtain template DNA for PCR (Adel et al., 2015; Carroll et al., 1999; Gurgulova et al., 2017).

\subsection{S rRNA gene amplification, sequencing, and phylogenetic analysis}

Colony PCR was used for amplification of 16s rRNA gene by suspending isolated bacterial colonies in Tris EDTA buffer and boiling for 10 minutes in the water bath. The cell debris was pelleted down by centrifugation at $6000 \mathrm{rpm}$ for five minutes and the supernatant was used as a template for PCR. Primers 27F (5'-AGAGTTTGATCMTGGCTCAG-3') and $1492 \mathrm{R}$ (5'-TACGGYTACCTTGTTACGACTT-3') were used with reaction conditions: initial denaturation at $94^{\circ} \mathrm{C}$ for $2 \mathrm{~min}$, followed by 30 cycles at $94^{\circ} \mathrm{C}$ for $1 \mathrm{~min}, 50^{\circ} \mathrm{C}$ for $1 \mathrm{~min}$ and $72^{\circ} \mathrm{C}$ for $1: 30 \mathrm{~min}$, and a final extension at $72^{\circ} \mathrm{C}$ for $10 \mathrm{~min}$. The purified PCR products were sequenced through the Sanger method. Sequence homology was analyzed using the Basic Local Alignment Search Tool (BLAST) while phylogenetic analysis was carried out through MEGA 6.0 using the Neighbour Joining method (Pavlopoulos et al., 2010).

\subsection{Experimental design and data collection}

The experiment was laid down in Completely Randomized Design (CRD) with three replications. At the onset of the $4^{\text {th }}$ instar, 50 larvae were kept in each replication. Data on different parameters were recorded at the end of the $5^{\text {th }}$ instars i.e. larval weight and larval length was recorded. Larval weight was calculated by taking the mean weight of five larvae whereas larval length $(\mathrm{cm})$ was recorded by taking the mean length of five randomly selected larvae at the end of the $5^{\text {th }}$ instar before the onset of cocoon spinning. Cocoon weight $(\mathrm{g})$ was recorded at the end of the spinning.

Cocoon weight $(\mathrm{g})$, shell weight $(\mathrm{g})$, and cocoon shell percentage were calculated by the following formula 1,2 and 3 .

$$
\text { Cocoon weight }(g)=\frac{\begin{array}{l}
\text { weight }(g) \text { of } 5 \text { female cocoons }+ \\
\text { weight }(g) \text { of } 5 \text { male cocoons }
\end{array}}{10}
$$

$$
\begin{aligned}
& \text { Shell Weight }(g)=\text { Cocoon weight }(g) \\
& \text { with pupa-Cocoon weight }(g) \text { without pupa }
\end{aligned}
$$

$$
\text { Shell percentage }=\frac{\text { Cocoon shell weight }(g)}{\text { Cocoon weight }(g)} \times 100
$$

The data were subjected to Analysis of Variance (ANOVA) and means were compared by applying Tukey's test (Steel \& Torrie, 1980; Tukey, 1949).

\section{Results}

\subsection{Biochemical characterization}

We explored the impact of Penicillin, Tetracycline, Amoxicillin, Ampicillin, and Erythromycin on the silkworm larval weight, larval length, cocoon weight, and gut inhabiting bacteria. Biochemical characterization showed that all strains (HG1, HG2, HG3, DG1, DG2, and DG3) were positive for the catalase test. Similarly, all strains showed a negative result for the Mannitol Utilization Test (as shown in Table 1). The sensitivity (S) or the resistivity (R) of HG1, HG2, HG3, DG1, DG2, and DG3 isolates to antibiotics was determined by observing the absence or presence of growth around the discs. Those isolates which showed growth around antibiotics were considered resistant to the corresponding antibiotics, whereas the isolates whose growth was inhibited by the antibiotics were considered sensitive.

In the present study, we isolated and identified bacterial strains $(n=06)$ from the gut of healthy and diseased silkworm larvae. Based on the 16S rRNA gene sequence, isolated bacteria showed close relation with Serratia spp., Bacillus spp., and Pseudomonas spp. The strains were found positive for the catalase and the citrate utilization test, but all were negative for the mannitol test. Notably, 83.3\% of strains were resistant to Penicillin, Tetracycline, Amoxicillin, Ampicillin, and Erythromycin but $16.6 \%$ showed antibiotic susceptibility to the above-mentioned commonly used antibiotics. Biochemical characterization revealed that all bacterial strains were able to show catalase activity, but no one showed activity for the mannitol utilization. Similarly, all strains showed citrate utilization, except HG3 (as shown in Table 1). All the strains were found resistant against antibiotics used in this study, except DG1, which showed sensitivity (as shown in Table 2).

\subsection{Phylogenetic analysis}

Molecular identification of the isolated bacterial strains was done after amplification and sequencing of the 16S rRNA gene (See Figure 1). Phylogenetic analysis demonstrated that bacterial strain DG2 and DG1 showed close relation with Serratia marcescens and Bacillus halotolerans, respectively, while other strains (DG3, HG1, HG2, and HG3) showed relatedness to Pseudomonas

Table 1. Biochemical characterization of different bacterial strains.

\begin{tabular}{cccc}
\hline Samples & $\begin{array}{c}\text { Catalase } \\
\text { Test }\end{array}$ & $\begin{array}{c}\text { Mannitol } \\
\text { Test }\end{array}$ & Citrate Test \\
\hline HG1 & + & - & + \\
HG2 & + & - & + \\
HG3 & + & - & - \\
DG1 & + & - & + \\
DG2 & + & - & + \\
DG3 & + & - & + \\
\hline
\end{tabular}

"+" represents positive results whereas "-" means negative results for the corresponding test. 
Table 2. Antimicrobial susceptibility of isolated bacterial strains.

\begin{tabular}{cccccc}
\hline Samples & Penicillin & Tetracycline & Amoxicillin & Ampicillin & Erythromycin \\
\hline HG1 & $\mathrm{R}$ & $\mathrm{R}$ & $\mathrm{R}$ & $\mathrm{R}$ & $\mathrm{R}$ \\
$\mathrm{HG} 2$ & $\mathrm{R}$ & $\mathrm{R}$ & $\mathrm{R}$ & $\mathrm{R}$ & $\mathrm{R}$ \\
$\mathrm{HG} 3$ & $\mathrm{R}$ & $\mathrm{R}$ & $\mathrm{R}$ & $\mathrm{R}$ & $\mathrm{S}$ \\
$\mathrm{DG} 1$ & $\mathrm{~S}$ & $\mathrm{~S}$ & $\mathrm{~S}$ & $\mathrm{R}$ & $\mathrm{S}$ \\
$\mathrm{DG} 2$ & $\mathrm{R}$ & $\mathrm{R}$ & $\mathrm{R}$ & $\mathrm{R}$ & $\mathrm{R}$ \\
$\mathrm{DG} 3$ & $\mathrm{R}$ & $\mathrm{R}$ & $\mathrm{R}$ & $\mathrm{R}$ \\
\hline
\end{tabular}

$\mathrm{R}$ and $\mathrm{S}$ represent "resistivity" and "sensitivity", respectively.

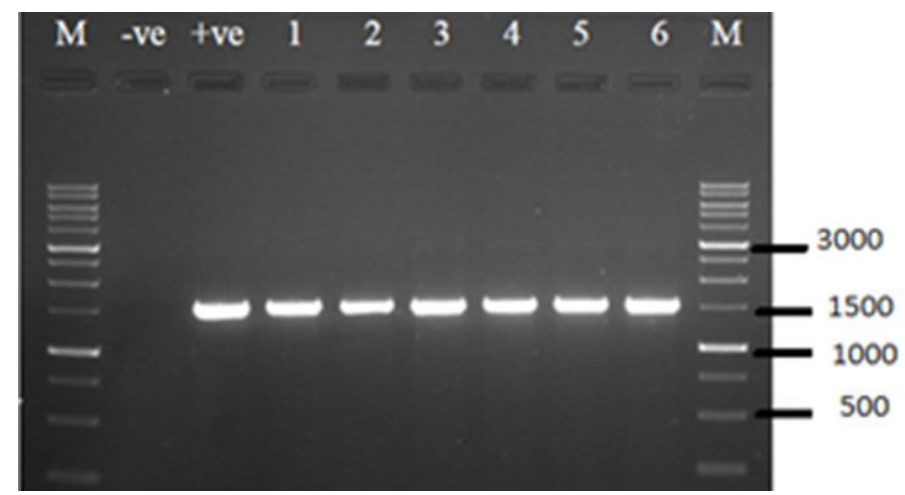

Figure 1. Amplification of $16 \mathrm{~S}$ rRNA gene ( $1500 \mathrm{bp}$ ) of isolated bacterial strains; lane $1=\mathrm{HG} 1$, lane 2 = HG2, lane $3=\mathrm{HG} 3$, lane 4 = DG1, lane 5 = DG2, lane 6 = DG3, $-\mathrm{ve}=$ negative control, +ve = positive control, $\mathrm{M}=1 \mathrm{~kb}$ DNA marker.

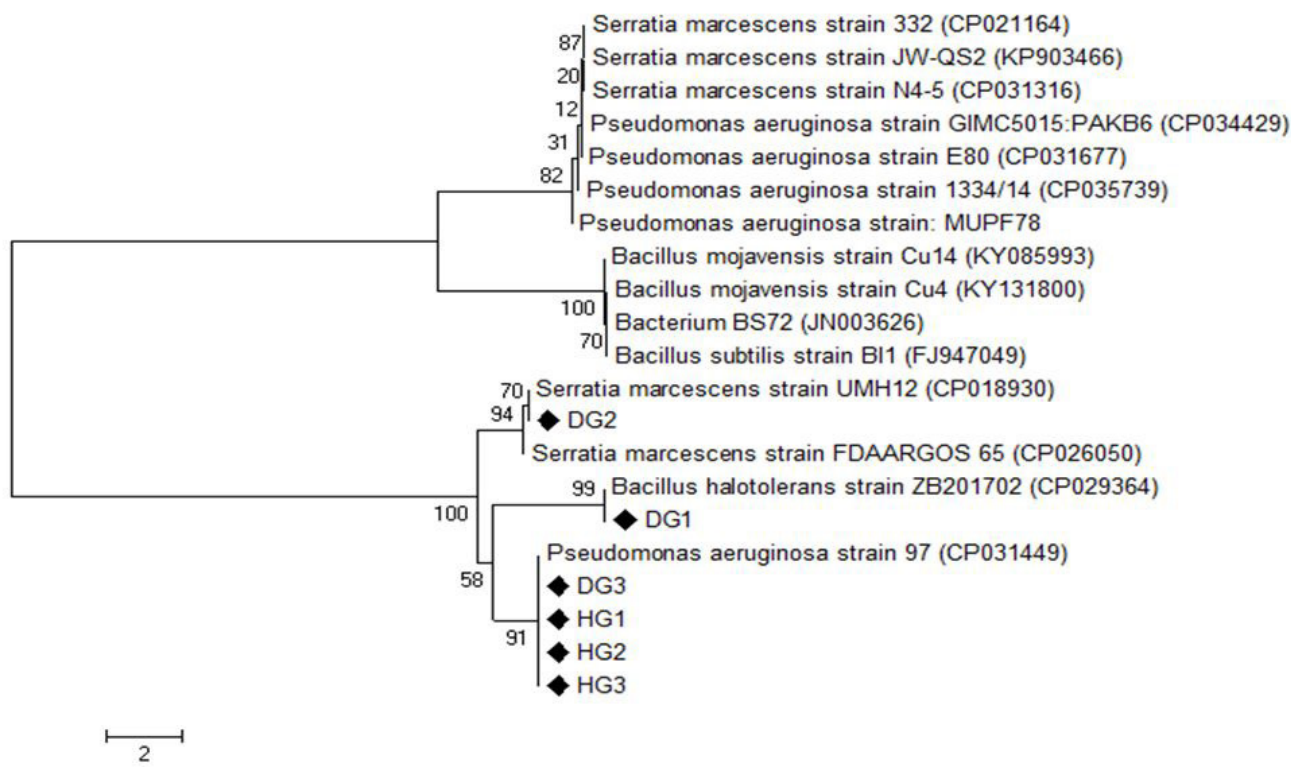

Figure 2. Phylogenetic relationship and identification of bacterial strains isolated in this study based on 16S rRNA gene sequence through Neighbor Joining method using 1000 bootstrap replicates.

aeruginosa (See Figure 2). When compared to each other HG1, HG2, HG3, and DG3 clustered together into the same clade but DG1 and DG2 were placed separately in phylogenetic tree (See Figure 3).
The sequences of the isolated strains were submitted to GenBank under accession numbers MK625483 (HG1), MK625484 (HG2), MK625485 (HG3), MK625486 (DG1), MK625487 (DG2), and MN073211 (DG3). 
Table 3. Performance of silkworm larvae under different treatment groups for larval weight, larval length, cocoon weight, shell weight, and cocoon shell percentage.

\begin{tabular}{cccccc}
\hline Treatment & $\begin{array}{c}\text { Larval length } \\
(\mathbf{c m})\end{array}$ & Larval weight $(\mathbf{g})$ & Cocoon weight $(\mathbf{g})$ & Shell weight $(\mathbf{g})$ & $\begin{array}{c}\text { Cocoon shell } \\
\text { percentage }\end{array}$ \\
\hline Penicillin & $5.84 \pm 0.02^{\mathrm{a}}$ & $6.88 \pm 0.06^{\mathrm{a}}$ & $1.33^{\mathrm{a}}$ & $0.233^{\mathrm{a}}$ & $17.46^{\mathrm{a}}$ \\
Tetracycline & $5.75 \pm 0.06^{\mathrm{ab}}$ & $6.66 \pm 0.07^{\mathrm{b}}$ & $1.28^{\mathrm{b}}$ & $0.213^{\mathrm{b}}$ & $16.56^{\mathrm{b}}$ \\
Ampicillin & $5.64 \pm 0.03^{\mathrm{bc}}$ & $6.18 \pm 0.04^{\mathrm{c}}$ & $1.25^{\mathrm{bc}}$ & $0.197^{\mathrm{c}}$ & $15.81^{\mathrm{bc}}$ \\
Erythromycin & $5.58 \pm 0.04^{\mathrm{c}}$ & $6.07 \pm 0.04^{\mathrm{c}}$ & $1.24^{\mathrm{bc}}$ & $0.196^{\mathrm{c}}$ & $15.78^{\mathrm{bc}}$ \\
Amoxicillin & $5.58 \pm 0.05^{\mathrm{c}}$ & $5.67 \pm 0.06^{\mathrm{d}}$ & $1.23^{\mathrm{c}}$ & $0.189^{\mathrm{cd}}$ & $15.34^{\mathrm{c}}$ \\
Control & $5.41 \pm 0.09^{\mathrm{d}}$ & $5.37 \pm 0.07^{\mathrm{e}}$ & $1.21^{\mathrm{c}}$ & $0.181^{\mathrm{d}}$ & $14.98^{\mathrm{c}}$ \\
\hline
\end{tabular}

Means in a column that have no superscript in common are significantly different from each other (Tukey's HSD, P<0.05).

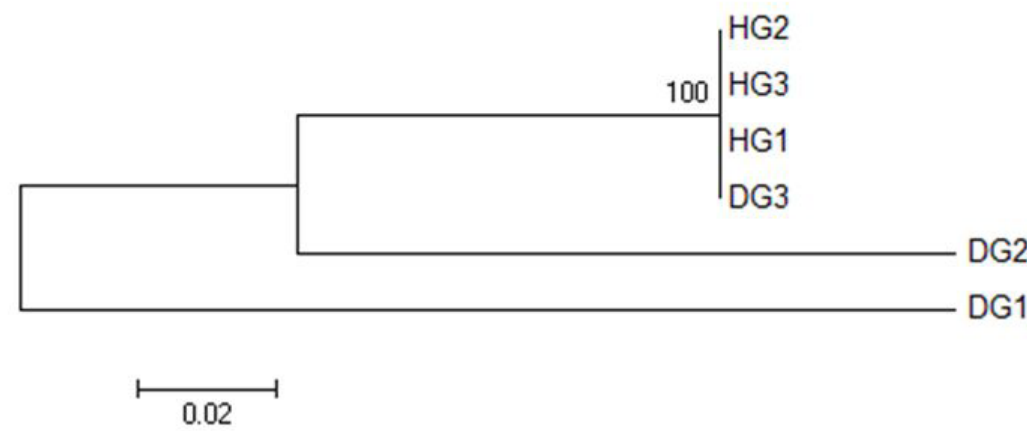

Figure 3. Phylogenetic relationship of bacterial strains isolated in this study with each other based on $16 \mathrm{~S}$ rRNA gene sequence through Neighbor-Joining method using 1000 bootstrap replicates.

\subsection{Effect on silkworm larval weight and larval length}

The data collected at the end of the $5^{\text {th }}$ larval instar before the cocoon spinning indicated significantly higher mean larval length in groups treated with antibiotics as compared to the control group i.e. Penicillin $(5.84 \mathrm{~cm})$ and Tetracycline $(5.75 \mathrm{~cm})$ were not significantly different with each but significantly different from all other groups (as shown in Table 3). Similarly, mean larval weight demonstrated significant differences in antibiotic-treated larvae as compared to control. Penicillin (6.88g), Tetracycline (6.66g), and Ampicillin (6.18g).

\subsection{Effect on cocoon weight, shell weight and cocoon shell \%}

The results indicated that cocoon weight, shell weight, and cocoon shell percentage indicated significant differences (as shown in Table 3). The highest mean cocoon weight was recorded for cocoons spun by larvae reared on leaves treated with penicillin (1.33g) followed by Tetracycline (128g) and Ampicillin (125g). Maximum shell weight $(0.233 \mathrm{~g})$ and cocoon shell percentage (17.46\%) was yielded by cocoons whereas maximum obtained from larvae reared on leaves treated with Penicillin.

\section{Discussion}

The diversity of insect gut microbial fauna is determined by various factors i.e. rearing conditions, developmental stage, diet, and phylogeny of the host (Chen et al., 2016; Martinson et al., 2017; Yun et al., 2014). In our study, bacterial diversity of silkworm gut showed the presence of Serratia marcescens, Pseudomonas aeruginosa, and Bacillus halotolerans isolated from the diseased larvae. The phylogenetic analysis showed that four (HG1, HG2, HG3 \& DG3) out of six strains were closely related with each other whereas distantly related with DG2 and DG1. It is more likely that the host phylogeny has a close association with the presence of these bacterial strains. It has been reported that host genetics plays pivotal role in determining the microbial community in mulberry-feeding lepidopteran insect fauna (Campbell et al., 2012). The bacterial strains i.e. HG1, HG2, HG3, DG3 (Pseudomonas aeruginosa), DG1 (Bacillus halotolerans), and DG2 (Serratia marcescens) were identified based on 16S rRNA gene sequencing. Bacteria have been reported as a potential causative agent of various infections in silkworms i.e. flacherie is more prevalent in the areas with elevated temperature $\left(30^{\circ} \mathrm{C}\right)$ and less than $80 \%$ relative humidity (Choudhury et al., 2002). Mulberry feed, developmental stages, and gender of the silkworm determine the bacterial gut communities (Liang et al., 2014; Sun et al., 2016). In the control group, our results indicated significantly lower means for biological and commercial attributes associated with silkworm larvae and cocoons, respectively. The mulberry leaves may likely be of poor nutritive value and larvae were unable to produce antibacterial factor in enough quantity. This could have 
lowered the performance of silkworm larvae. In an earlier study, significant reduction in the total protein content of the silk glands of flacherie infected larvae (Rajasekhar \& Pathak, 1994). Similar results were reported in an earlier study on the silkworm microbiota reporting that poor nutritive value lowers the performance of silkworm larvae for biological and commercial traits (Manimegalai \& Chandramohan, 2005). Earlier studies concluded that the use of antibiotics eliminated intestinal bacteria and enhanced the chance of the susceptibility of the silkworms to S. marcescens and baculovirus (Rajagopal, 2009). Antibiotics destroy or inhibit undesirable bacteria in the gut and thus improving absorption of food (Phillips et al., 2004; Venkatesh Kumar \& Srivastava, 2010). Larval weight and length showed a significant increase when larvae were fed leaves treated with antibiotics (Mahdi et al., 2017). Vitamins and antibiotics enriched feeding resulted in the enhancement of cocoon weight, shell weight and shell ratio (Venkatesh Kumar \& Srivastava, 2010). Administration of penicillin and streptomycin to $5^{\text {th }}$ instar larvae of mulberry silkworm resulted in the increased body weight (Murthy \& Sreenivasaya, 1953). The supplementation of tetracycline and ampicillin to silkworm larvae resulted in significant increase in cocoon weight and shell percentage (SAVITHRI, 2007). Antibiotics administration with different concentration significantly improved the biological and economic parameters of silkworm larvae and cocoon, respectively (SAVITHRI, 2007). Antibiotic supplementation in healthy larvae could lead to the improvement in the biochemical parameters (Savitri \& Mohan, 2003). Use of antibiotics during larval rearing has prophylactic effect and could lead to harvest better cocoon crops. The results demonstrated that antibiotics seem to assist in the building up the resistance in the larvae, thus, minimizing the mortality and enhancing the growth of larvae

\section{Conclusion}

Isolated bacterial strains showed close relation with Serratia spp., Bacillus spp. and Pseudomonas spp. The results demonstrate that the mulberry silkworm fed on antibiotictreated leaves yielded significantly higher means of cocoon weight, shell weight, and shell percentage. Larval mortality was not observed in the antibiotic-treated groups. Similarly, improved larval weight and larval length was recorded in treatment groups as compared to control.

\section{References}

ADEL, A., ABOU, E.-E., ABDELALEIM, Y.F. and KARIMAN, M.M., 2015. Isolation and identification of some bacteria causing infections in Silkworm (Bombyx mori L.). International Journal of Current Research in Biosciences and Plant Biology, vol. 2, no. 12, pp. 69-74.

AYOADE, F., OYEJIDE, N.E. and FAYEMI, S.O., 2014. Isolation, identification, antibiogram and characterization of bacterial pathogens of the silkworm, Bombyx mori in South-West Nigeria. The Journal of Biological Sciences, vol. 14, no. 6, pp. 425-430. http://dx.doi.org/10.3923/jbs.2014.425.430.
BAUER, A., KIRBY, W., SHERRIS, J.C. and TURCK, M., 1966. Antibiotic susceptibility testing by a standardized single disk method. American Journal of Clinical Pathology, vol. 45, no. 4, pp. 493-496.

CAMPBELL, J.H., FOSTER, C.M., VISHNIVETSKAYA, T., CAMPBELL, A.G., YANG, Z.K., WYMORE, A., PALUMBO, A.V., CHESLER, E.J. and PODAR, M., 2012. Host genetic and environmental effects on mouse intestinal microbiota. The ISME Journal, vol. 6, no. 11, pp. 2033-2044. http://dx.doi.org/10.1038/ismej.2012.54. PMid:22695862.

CARROLL, N.M., ADAMSON, P. and OKHRAVI, N., 1999. Elimination of bacterial DNA from Taq DNA polymerases by restriction endonuclease digestion. Journal of Clinical Microbiology, vol. 37, no. 10, pp. 3402-3404. http://dx.doi.org/10.1128/JCM.37.10.34023404.1999. PMid:10488219.

CHEN, B., TEH, B.-S., SUN, C., HU, S., LU, X., BOLAND, W. and SHAO, Y., 2016. Biodiversity and activity of the gut microbiota across the life history of the insect herbivore Spodoptera littoralis. Scientific Reports, vol. 6, pp. 29505. http://dx.doi.org/10.1038/ srep29505. PMid:27389097.

CHOUDHURY, A., GUHA, A., YADAV, A., UNNI, B.G. and ROY, M.K., 2002. Causal organism of flacherie in the silkworm Antheraea assama Ww: isolation, characterization and its inhibition by garlic extract. Phytotherapy Research, vol. 16, no. suppl. 1, pp. S89-S90. http://dx.doi.org/10.1002/ptr.810. PMid:11933151.

DILLON, R. and DILLON, V., 2004. The gut bacteria of insects: nonpathogenic interactions. Annual Review of Entomology, vol. 49, no. 1, pp. 71-92. http://dx.doi.org/10.1146/annurev. ento.49.061802.123416. PMid:14651457.

GURGULOVA, K.I., OROZOVA, P.S., PANAYOTOV, M.V., ZHELYAZKOVA, I.Z., TAKOVA, S.B. and GUNCHEVA, R.P., 2017. Isolation and identification of some gram-positive bacteria causing infections in Silkworm Bombyx mori L. (Lepidoptera). Acta Zoologica Bulgarica, suppl. 8, pp. 139-144.

HOU, Y., ZOU, Y., WANG, F., GONG, J., ZHONG, X., XIA, Q. and ZHAO, P., 2010. Comparative analysis of proteome maps of silkworm hemolymph during different developmental stages. Proteome Science, vol. 8, pp. 45. http://dx.doi.org/10.1186/1477-5956-845. PMid:20822545.

HUSSAIN, M., AHMAD KHAN, S., NAEEM, M., AQIL, T., KHURSHEED, R. and UL MOHSIN, A., 2011a. Evaluation of silkworm lines against variations in temperature and $\mathrm{RH}$ for various parameters of commercial cocoon production. Psyche, vol. 2011, pp. 1-11. http://dx.doi.org/10.1155/2011/145640.

HUSSAIN, M., NAEEM, M., KHAN, S.A., BHATTI, M.F. and MUNAWAR, M., 2011b. Studies on the influence of temperature and humidity on biological traits of silkworm (Bombyx mori L.; Bombycidae). African Journal of Biotechnology, vol. 10, no. 57, pp. 12368-12375.

ISLAM, M.R., ALI, M.A.O., PAUL, D.K., SHAHEEN, S., BANU, N.A. and ISLAM, M.R., 2004. Effect of salt, nickel chloride supplementation on the growth of Silkworm, Bombyx mori L. (Lepidoptera: bombycidae). The Journal of Biological Sciences, vol. 4, no. 2, pp. 170-172. http://dx.doi.org/10.3923/jbs.2004.170.172.

KANWAL, M., HUSSAIN, M., ABBAS, Z., KHAN, S.A., ZAFAR, F. and HURSHEED, R., 2018. Yield performance of Bulgarian race of silkworm fed on local mulberry supplemented with vitamins and amino acids. Biologia (Pakistan), vol. 64, no. 1, pp. 45-53.

LIANG, X., FU, Y. and LIU, H., 2015. Isolation and characterization of enzyme-producing bacteria of the silkworm larval gut in bioregenerative life support system. Acta Astronautica, vol. 116, pp. 247-253. http://dx.doi.org/10.1016/j.actaastro.2015.07.010.

LIANG, X., FU, Y., TONG, L. and LIU, H., 2014. Microbial shifts of the silkworm larval gut in response to lettuce leaf feeding. Applied 
Microbiology and Biotechnology, vol. 98, no. 8, pp. 3769-3776. http://dx.doi.org/10.1007/s00253-014-5532-y. PMid:24493569.

MAHDI, S.H., ROKONUZZAMAN, M., UDDIN, M.A. and KAMRUL, M., 2017. The effects of amoxicillin, oxytetracyclin and doxycyclin on the growth and development of silkworm, Bombyx mori L. Journal of Entomology and Zoology Studies, vol. 5, no. 6, pp. 1316-1321.

MAHMOUD, S.M., TAHA, R. and SAAD, I.A.I., 2012. Antibiotic (Gentamicin) impact on bacterial flacherrie disease of silkworm, Bombyx mori L. Egyptian Academic Journal of Biological Sciences: Entomology, vol. 5, no. 2, pp. 55-63. http://dx.doi.org/10.21608/ eajbsa.2012.14792.

MANIMEGALAI, S. and CHANDRAMOHAN, N., 2005. Botanicals for the management of bacterial flacherie of silkworm, Bombyx mori L. Sericologia, vol. 45, no. 1, pp. 51-61.

MARTINSON, V.G., DOUGLAS, A.E. and JAENIKE, J., 2017. Community structure of the gut microbiota in sympatric species of wild Drosophila. Ecology Letters, vol. 20, no. 5, pp. 629-639. http:// dx.doi.org/10.1111/ele.12761. PMid:28371064.

MOHANTA, M., SAHA, A., SALEH, D., HASAN, M., 2013. Bioefficacy of some plant extracts against pathogenic bacteria isolated from diseased silkworm larvae. University Journal of Zoology, vol. 32, pp. 9-14.

MURTHY, M.R. and SREENIVASAYA, M., 1953. Effect of antibiotics on the growth of the Silkworm, Bombyx mori L. Nature, vol. 172, no. 4380, pp. 684-685. http://dx.doi.org/10.1038/172684a0. PMid:13099312.

NAYAK, P., HIMANTHARAJ., RAHMATHULLA., VINDYA. and RAJAN., 2006. Influence of antibiotic on feed conversion efficiency of mulberry silkworm (Bombyx mori L.). Animal Biology (Leiden, Netherlands), vol. 56, no. 1, pp. 13-22. http://dx.doi. org/10.1163/157075606775904731.

PAVLOPOULOS, G.A., SOLDATOS, T.G., BARBOSA-SILVA, A. and SCHNEIDER, R., 2010. A reference guide for tree analysis and visualization. BioData Mining, vol. 3, no. 1, pp. 1-24. http:// dx.doi.org/10.1186/1756-0381-3-1. PMid:20175922.

PHILLIPS, I., CASEWELL, M., COX, T., DE GROOT, B., FRIIS, C., JONES, R., NIGHTINGALE, C., PRESTON, R. and WADDELL, J., 2004. Does the use of antibiotics in food animals pose a risk to human health? A critical review of published data. The Journal of Antimicrobial Chemotherapy, vol. 53, no. 1, pp. 28-52. http:// dx.doi.org/10.1093/jac/dkg483. PMid:14657094.

RAJAGOPAL, R., 2009. Beneficial interactions between insects and gut bacteria. Indian Journal of Microbiology, vol. 49, no. 2, pp. 114-119. http://dx.doi.org/10.1007/s12088-009-0023-z. PMid:23100759.

RAJASEKHAR, C. and PATHAK, J., 1994. Effects of bacterial flacherie on the total protein concentration of silkgland and haemolymph of Bombyx mori L. Journal of Sericulture, vol. 2, pp. 48-50.

RAJENDRA, B., CHANDRASHEKHAR, H.J. and AVHAD, S.B., 2011. Prevalence of Muscardine Disease in Different Silkworm Hybrid,
Bombyx mori L. under Agro-climatic Conditions in Aurangabad (MS), India. Journal of Life Science, vol. 5, pp. 136-138.

RIAZ, H., MALIK, F., RAZA, A., HAMEED, A., AHMED, S., SHAH, P.A. and HUSSAIN, S., 2011. Assessment of antibiotic prescribing behavior of consultants of different localities of Pakistan. African Journal of Pharmacy and Pharmacology, vol. 5, no. 5, pp. 596-601. http://dx.doi.org/10.5897/AJPP11.051.

SAVITRI, G. and MOHAN, P.M., 2003. In vitro screening of antibiotics against Bacillus cogulans. Indian Journal of Sericulture, vol. 42, no. 1, pp. 25-28.

SAVITHRI, G., 2007. In Vivo Effects of Antibiotics on Silkworm Bombyx mori L. Infected with Bacillus coagulans, International Journal of Industrial Entomology, vol. 15, no. 1, pp. 9-16.

SHARMA, M. and KEDAR, N., 2013. Constraints in adoption of recommended sericulture production technology in Korba district of Chhattisgarh. Agriculture Update, vol. 8, no. 3, pp. 357-363.

SIDHU, N. and SINGH, N., 1968. Resistance of silkworm mutant strains and breeds and inductive factors leading to the development of grasserie and flacherie diseases in silkworm, Bombyx mori L. Indian Journal of Sericulture, vol. 7, pp. 27-31.

STEEL, R.G. and TORRIE, J.H., 1980. Principles and procedures of statistics. New York: McGraw-Hill Book Co. Inc., 481 p.

SUN, Z., LU, Y., ZHANG, H., KUMAR, D., LIU, B., GONG, Y., ZHU, M., ZHU, L., LIANG, Z., KUANG, S., CHEN, F., HU, X., CAO, G., XUE, R. and GONG, C., 2016. Effects of BmCPV infection on silkworm Bombyx mori intestinal bacteria. PLoS One, vol. 11, no. 1, pp. 1-17. http://dx.doi.org/10.1371/journal.pone.0146313. PMid:26745627.

TODMAL, S., KHALACHE, P., GAIKWAD, J. and JADHAV, R., 2013. Constraints faced by farmers in adoption of sericulture production technology. Advance Research Journal of Social Science, vol. 4, no. 1, pp. 112-114.

TUKEY, J.W., 1949. Comparing individual means in the analysis of variance. Biometrics, vol. 5, no. 2, pp. 99-114. http://dx.doi. org/10.2307/3001913. PMid:18151955.

VENKATESH KUMAR, R. and SRIVASTAVA, A., 2010. Relevance of antibiotics with reference to sericulture industry. International Journal of Science and Nature, vol. 1, no. 2, pp. 97-100.

VENKATESH, B., KUMARAN, T., 2015. Sensitivity and antibiogram studies on pathogenic microbes isolated from the silkworm Bombyx mori L. The Pharma Innovation, vol. 4, no. 6(pt B), pp. 101-103.

YUN, J.-H., ROH, S.W., WHON, T.W., JUNG, M.-J., KIM, M.-S., PARK, D.-S., YOON, C., NAM, Y.-D., KIM, Y.-J., CHOI, J.-H., KIM, J.Y., SHIN, N.R., KIM, S.H., LEE, W.J. and BAE, J.W., 2014. Insect gut bacterial diversity determined by environmental habitat, diet, developmental stage, and phylogeny of host. Applied and Environmental Microbiology, vol. 80, no. 17, pp. 5254-5264. http://dx.doi.org/10.1128/AEM.01226-14. PMid:24928884. 